\title{
Seasonal estimates of actual evapotranspiration from Tamarix ramosissima stands using 3-dimensional eddy covariance
}

\author{
James R. Cleverly ${ }^{1^{*}}$ \\ Clifford N. Dahm ${ }^{1}$ \\ James R. Thibault ${ }^{1}$ \\ David J. Gilroy ${ }^{1}$ \\ Julie E. Allred Coonrod ${ }^{2}$ \\ November 7, 2001
}

Accepted for publication in Journal of Arid Environments as of 8 January 2002.

1 Department of Biology

University of New Mexico

Albuquerque, NM 87131-1091
2 Department of Civil Engineering University of New Mexico Albuquerque, NM 87131-1351

*Correspondence: cleverly@sevilleta.unm.edu, (505) 277-9341

Short Title: Evapotranspiration from riparian $T$. ramosissima stands Abstract

This study addresses the pattern of evapotranspiration (ET) throughout the growing season for Tamarix ramosissima between regularly flooded and unflooded sites. Spatial and temporal ET 
patterns along the Middle Rio Grande demonstrated considerable variability. ET at the unflooded site was $61 \%$ of ET at the flooded site, totaling 74 and $122 \mathrm{~cm} \mathrm{yr}^{-1}$ at the unflooded and flooded sites, respectively. The seasonal coefficient of variability was $37 \%$ and $38 \%$ at the flooded and unflooded sites, respectively. Spatial variability was $39 \%$. Determining ET patterns with respect to the spatial, ecological and temporal setting improves riparian zone ET depletion predictions.

Keywords: Rio Grande, flooding, seasonal variability, cottonwood, saltcedar, exotic species, restoration 


\section{Introduction}

Riparian areas are prominent features within arid and semi-arid landscapes. They provide important economic, recreational and natural resources in disproportion to their limited spatial extent. Riparian water resources in the southwestern U.S. are in great demand for use in agriculture, urban development and ecosystem services (Jackson et al., 2001). Such conflicts of interests are especially acute during La Niña years, when water resources are commonly scarce (Molles \& Dahm, 1990). Along the Middle Rio Grande, equitable assignment of water to competing groups and ecosystems has been hampered by the elusiveness of an accurate water budget. One of the main components lacking good quantification in the Middle Rio Grande water budget is evapotranspiration (ET) from the riparian forest, or bosque as it is known in New Mexico.

Presently, ET estimates used in water budgets of the Middle Rio Grande bosque are based upon the modified Blaney-Criddle crop coefficient model (cf Hansen \& Gorbach, 1997):

$$
\mathrm{u}=\sum_{\mathrm{i}=1}^{12} \mathrm{k} \frac{\overline{\mathrm{T}_{\mathrm{i}}}}{\overline{\mathrm{p}_{\mathrm{i}}}},
$$

where $u$ is the consumptive water use, $i$ is the month of the year, $k$ is the empirical crop coefficient, $\overline{\mathrm{T}}$ is the mean monthly temperature, and $\overline{\mathrm{p}}$ is the mean monthly proportion of daylight hours (Jensen et al., 1990). Semi-empirical methods like the Blaney-Criddle model perform well over uniform vegetation like crops, but spatial, inter-annual and even seasonal variability is often poorly represented in monthly temperature and crop coefficient estimates, assuming of course that temperature controls ET in such a simple manner. Further limitations on such models are related to the applicability of crop coefficient data sources. For example, Hansen \& Gorbach (1997) applied a model to the Middle Rio Grande bosque for Populus deltoides subsp. wislizenii (S. Wats.) Eckenw. in which the crop coefficient was determined from a three-year-old, well-watered Populus fremontii S. Watson plantation. It is currently unknown whether crop coefficients developed from juveniles provide an accurate estimate of ET above mature stands that are exposed to seasonal cycles of flooding and drought. Such variability likely limits the accuracy and utility of crop coefficient-based ET estimates.

Determining sources of spatial and temporal variability in bosque ET will contribute to a more accurate quantification of actual ET. Many ecosystem characteristics vary in both time and space, thereby contributing to both spatial and temporal variability in ET. For example, the occurrence of flooding varies both spatially, peaking where the impact of anthropomorphic channelization and flow regulation is minimal, and temporally, peaking during spring snowmelt and immediately following strong monsoon 
precipitation in July and August. Likewise, leaf area index (LAI) is a measure of the evaporative surface area at a site that varies spatially with species composition and plant density and varies temporally with the phenology of the species occurring at a given site.

Historically, spring flooding along the Rio Grande was common in response to snowmelt (Slack et al., 1993). Recent diminishment of these floods has reduced decomposition (Molles et al., 1995) and historic ecosystem function (Bayley, 1995; Molles et al., 1998). Hydrologic modification, furthermore, directly impacts the physiology, growth and survivorship of native species and creates an opportunity for invasion by exotic species (Smith et al., 1991; Auble et al., 1994).

In the western U.S., the dominating presence of the exotic species Tamarix ramosissima Ledeb. (saltcedar) and Elaeagnus angustifolia L. (Russian olive) impacts the magnitude of ET in the water budget (Molles et al., 1998). It has been sometimes presumed that $T$. ramosissima transpires more than co-occurring native species, although there is a paucity of direct comparisons between $T$. ramosissima and $P$. deltoides, especially at the stand-level. While some have begun to question the conventional wisdom that $T$. ramosissima is a spendthrift water consumer (Anderson, 1998), comparisons between $T$. ramosissima and other members of the Salicaceae ( $P$. fremontii subsp. fremontii, Salix gooddingii, and $S$. exigua) demonstrate that $T$. ramosissima probably does transpire more than less stress tolerant cottonwoods and willows (Busch \& Smith, 1995; Cleverly et al., 1997; Schaeffer et al., 2000).

The objectives of this research in the Middle Rio Grande bosque are (1) to determine the spatial and temporal patterns of actual evapotranspiration (AET) rates and (2) to characterize and explain spatial and temporal variability in $T$. ramosissima $\mathrm{ET}$. We hypothesized that ET would vary more across a season than between locations along the river. We further predicted that $T$. ramosissima at a flooded site would exhibit a greater stand-level ET than at an unflooded site. A growing season estimate of ET during 1999, along with the variability and error associated with the estimation of ET, has been developed from initial ET measurements at two sites along the Middle Rio Grande. These data for the growing season of 1999 are compared to previously published ET values originating from studies of varying duration at the leaf, canopy and stand level for $T$. ramosissima.

\section{Methods and Materials}

The location for this research is the Middle Rio Grande in New Mexico USA where dominant woody species are $T$. ramosissima and $P$. deltoides. $T$. ramosissima is a weedy invasive species (Christensen, 1962; Robinson, 1965; Brock, 1994) that can form monospecific stands where it has successfully invaded. $P$. deltoides is the dominant native woody species along the Middle Rio Grande where it forms an imposing canopy > $25 \mathrm{~m}$ tall in some locations. 
Growing season data were collected from two $T$. ramosissima stands along the Middle Rio Grande (Fig. 1). One of these sites is located on the Sevilleta National Wildlife Refuge (NWR) outside of San Acacia NM and upstream of San Acacia diversion dam ( $34^{\circ} 16^{\prime} \mathrm{N}, 106^{\circ} 52^{\prime} \mathrm{W}, 1430 \mathrm{~m}$ elev.). The Sevilleta NWR site does not undergo annual flooding and supports a relatively low LAI $(\approx 2.5$; Dahm et al., In press). The community contains a mixture of $T$. ramosissima, Distichlis spicata (L.) Greene, Atriplex L. spp, Salix exigua Nutt., and Prosopis pubescens Benth., but $T$. ramosissima and $D$. spicata dominate at this site. The other site, located at the Bosque del Apache NWR $\left(33^{\circ} 47^{\prime} \mathrm{N}, 106^{\circ} 53^{\prime} \mathrm{W}, 1375 \mathrm{~m}\right.$ elev.), was flooded during the spring and summer of 1999 , and a monospecific $T$. ramsosissima stand supports a relatively high LAI $(\approx 3.5$; Dahm et al., In press). At each site, a three-dimensional eddy covariance system (Campbell Scientific, Inc., Logan, UT) was mounted to a tower $2.5 \mathrm{~m}$ above the canopy. At both sites, the forested distance upwind in any direction was $>300 \mathrm{~m}$, exceeding the fetch for these tower heights under even extremely stable conditions. The primary system consisted of a CSAT3 three-dimensional sonic anemometer and a $\mathrm{KH} 20$ krypton hygrometer.

The eddy covariance system was oriented toward the south to take advantage of the predominant wind direction along the relatively uniform riparian corridor, thereby reducing data loss due to winds from behind the tower and anemometer block. The three-dimensional sonic anemometer measures wind speed in three dimensions 10 times per second. Likewise, the Krypton hygrometer measures vapor pressure at a frequency of $10 \mathrm{~Hz}$. The covariance between the vertical wind speed and vapor pressure are computed every $30 \mathrm{~min}$, and the latent heat flux (LE; $\mathrm{W} \mathrm{m}^{-2}$ ) is computed as

$$
L E=\lambda \overline{\text { w'e }}
$$

where $\lambda_{v}\left(2441 \mathrm{~kJ} \mathrm{~kg}^{-1}\right)$ is the latent heat of vaporization for water and $\overline{\mathrm{w}^{\prime} \mathrm{e}}$ is the 30-min covariance between the instantaneous deviation in vertical windspeed from the average vertical windspeed $\left(w^{\prime} ; \bar{w}=0 \mathrm{~m} \mathrm{~s}^{-1}\right)$ and the instantaneous deviation in water vapor pressure (e'). Sensible heat flux $\left(\mathrm{H} ; \mathrm{W} \mathrm{m}^{-2}\right)$ was computed as

$$
\mathrm{H}=\varrho_{\mathrm{a}} \mathrm{C}_{\mathrm{p}} \overline{\mathrm{w}^{\prime} \mathrm{T}} \text {, }
$$

where $\mathrm{e}_{a}\left(\mathrm{~kg} \mathrm{~m}^{-3}\right)$ is the density of air, $\mathrm{C}_{\mathrm{p}}$ is the specific heat of air $\left(\mathrm{J} \mathrm{g}^{-1}{ }^{\circ} \mathrm{C}^{-1}\right)$ and $\mathrm{T}^{\prime}$ is the instantaneous deviation in temperature. Temperature was measured throughout the growing season by the sonic anemometer (i.e., the virtual temperature) and part of the growing season by a very fragile FW05 fine wire thermocouple $(0.0127 \mathrm{~mm}$ diameter type E chromel-constantan). 
As well as daily eddy covariance measurements above the canopy, temperature and relative humidity $(\mathrm{RH})$ were monitored using an HMP45C temperature and $\mathrm{RH}$ probe at the top of the canopy: $5.7 \mathrm{~m}$ at the $T$. ramosissima flooded site and $4.2 \mathrm{~m}$ at the $T$. ramosissima unflooded site. Net radiation $\left(\mathrm{R}_{\mathrm{n}} ; \mathrm{W} \mathrm{m}^{-2}\right)$ was measured well above the CSAT3 using vented and cross calibrated Q7.1 net radiometers (Kustas, et al., 1998) and soil heat flux (G; $\mathrm{W} \mathrm{m}^{-2}$ ) was measured $8 \mathrm{~cm}$ below the soil surface using two HFT-3 soil heat flux plates at each site. All of the data were logged every 30 min using a CR23X. As with the eddy covariance system, all of the components were manufactured or re-marketed by Campbell Scientific, Inc. (Logan, UT). Sites were visited weekly to semiweekly to remove scale from sensors, check and replace desiccants, observe the state of the vegetation, and download data.

Closure of the energy balance was calculated as

$$
\mathrm{R}_{\mathrm{n}}=\mathrm{LE}+\mathrm{G}+\mathrm{H}+\text { closure. }
$$

Positive closure values are added to $\mathrm{H}$ and LE using the measured Bowen Ratio $\left(\beta=\frac{H}{L E}\right)$, thereby balancing the incoming and outgoing energy when $R_{n}$ exceeds $L E+G$ $+\mathrm{H}$. This closure calibration has been adopted because total closure error tends to exceed errors in measuring net radiation (Twine, et al., 2000). ET (mm day ${ }^{-1}$ ) from each tower was computed every 30 min as

$$
\mathrm{ET}=\frac{\mathrm{LE}}{\lambda_{\mathrm{v}} \mathrm{Q}_{\mathrm{W}}},
$$

where $\varrho_{w}\left(997 \mathrm{~kg} \mathrm{~m}^{-3}\right.$ at $\left.25^{\circ} \mathrm{C}\right)$ is the density of water. On days in which all $30 \mathrm{~min}$ values were present, daily ET was computed as the sum of daytime (i.e., when $R_{n}>0$ ) 30 min ET values. On days when one to four of the 30 min values were missing, a general linear regression model between $\mathrm{LE}$ and $\mathrm{R}_{\mathrm{n}}$ (Statistical Analysis Software, SAS Institute, Inc., Cary, NC) was used to estimate the missing data whenever the regression coefficient was significantly different from 0 (i.e., $p>0.05$ ). ET was not determined on days that did not match the above criteria. All daily means (e.g., mean daytime $\mathrm{RH}$ ) and totals (e.g., daily total ET) were smoothed with a 5-day moving average to identify dynamic trends from random variability throughout the growing season. Comparisons of the $\mathrm{ET}$ and $\mathrm{RH}$ time series was performed using power spectral and coherence analyses (SAS, SAS Institute, Inc., Cary, NC) on the autocorrelation functions. Annual total ET was determined from the integration of the seasonal ET amounts (Fig. 2) after estimating the missing data using the regression between ET at the two sites (Fig. 5). When both sites were missing data on the same day, linear interpolation was used to fill missing days.

Seasonal and spatial variability was determined from the data between ET onset and cessation dates, inclusively. Seasonal ET variability was determined using the 
coefficient of variation (Statistical Analysis Software, SAS Institute, Inc., Cary, NC). Spatial ET variability between these sites was computed as $1-m$, where $m$ is the slope of the regression shown in Figure 5; a 1:1 relationship (i.e., $\mathrm{m}=1$ ) indicates, on average, $100 \%$ similarity between sites, and lack of a significant relationship (i.e., $\mathrm{m}=$ 0 ), indicates $100 \%$ variability between sites.

Further ET data for $T$. ramosissima were compiled from the literature to obtain an a priori ET estimate in a variety of environmental conditions. Wherever possible, ET measurements in each paper were converted to common units for comparability between studies. The published ET values for $T$. ramosissima were distinguished by their level (i.e., leaf, canopy, or stand) and methodology (e.g., sap flux or Bowen Ratio).

\section{Results}

The date of ET onset (i.e., the date when ET $>1.0 \mathrm{~mm}^{\text {day }}{ }^{-1}$ ) occurred on 13 May at both the $T$. ramosissima dominated unflooded (Fig. 2) and the T. ramosissima flooded (data not shown) sites during 1999 along the Middle Rio Grande. Likewise, cessation of ET occurred simultaneously on 16 Oct 1999 at the $T$. ramosissima unflooded (Fig. 2) and flooded sites. These dates coincided with the start of springtime leaf development and the completion of autumnal senescence (Fig. 2). Between those dates, average daily ET rates were $5.4 \pm 0.2$ and $3.4 \pm 0.2 \mathrm{~mm}$ day $^{-1}$ at the flooded and unflooded sites, respectively. The corresponding maximal ET rates at the flooded and unflooded sites were 9.8 and $6.9 \mathrm{~mm} \mathrm{day}^{-1}$, respectively. The total ET from the $T$. ramosissima unflooded site during this 157 day growing period was $74 \mathrm{~cm}$ and was $122 \mathrm{~cm}$ at the $T$. ramosissima flooded site.

The coefficient of variation in seasonal ET was $37 \% \pm 4 \%\left(0.9\right.$ to $6.9 \mathrm{~mm}^{-1 a{ }^{-1}}$; Figs. 2 \& 3) at the unflooded site and $38 \% \pm 3 \%$ (1.3 to $9.8 \mathrm{~mm}^{-1 a y}{ }^{-1}$; data not shown) at the flooded site. Daily maximum and minimum canopy temperature also varied across the growing season (Fig. $3 \mathrm{~A}$ ) with an inconsistent relationship to variation in ET. During the growing season, but not before or after, daily average $\mathrm{RH}$ varied out of phase with growing season ET: ET increased when RH decreased and ET decreased when RH increased $\left(\mathrm{f}_{\mathrm{m}_{\mathrm{ET}}}=\mathrm{f}_{\mathrm{m}_{\mathrm{RH}}}=0.46 \mu \mathrm{Hz}\right.$ (25 day period), $\mathrm{K}=0.02 ;$ Fig. 3B). The same relationship was observed between ET and specific humidity (q; $\mathrm{g} \mathrm{m}^{-3}$; data not shown).

Mean daytime $R_{n}$ also fluctuated in synchrony with LE (Fig. 4). Mean daytime LE and $\mathrm{H}$ were inversely related throughout the growing season, wherein $\mathrm{H}$ declined when LE increased. Mean daytime $G$ was very minor throughout the year, and mean daytime closure varied between 0 and $150 \mathrm{~W} \mathrm{~m}^{-2}$. These closure values are equivalent to 1 and 0.60, respectively, using the Prueger et al., (1996) fraction of the energy balance due to closure calculation: 


$$
\text { frac }_{\text {closure }}=\frac{\mathrm{LE}+\mathrm{H}}{\mathrm{R}_{\mathrm{n}}+\mathrm{G}} .
$$

Closure was highest during July and August, corresponding to the monsoon period in central New Mexico.

Throughout the growing season, ET at the $T$. ramosissima flooded site consistently exceeded ET at the unflooded site. Average growing season ET at the unflooded site was $61 \%$ of the ET at the flooded site (Fig. 5), and spatial variability was estimated at $39 \% \pm 3 \%$. The shape of the ET trend was the same at both sites, varying in the same manner across the growing season. This relationship was strongest when ET $<5 \mathrm{~mm}$ day $^{-1}$; the residuals increased above $5 \mathrm{~mm}_{\text {day }}{ }^{-1}$ indicating a greater likelihood that ET at the Sevilleta NWR unflooded site was more or less than $61 \%$ of the ET at the Bosque del Apache NWR flooded site (Fig. 5). The y-intercept of this relationship (-0.02 mm day $^{-1}$; Fig. 5) was not significantly different from zero $(p=0.85)$.

\section{Discussion}

Annual ET at the unflooded site ranged from zero in winter to a maximum $(6.9 \mathrm{~mm}$ day $^{-1}$ ) in summer (Fig. 2). In addition to LE, $\mathrm{H}$ and closure fluctuated throughout the year (Fig. 4), so measurement period can strongly influence ET estimates in $T$. ramosissima (Table 2). Short-term estimates of ET during different parts of the year complicate most of the comparisons that can be made in Table 1. Average growing season ET, along with the length of the season, are the most valuable data to report for facilitating ET comparisons between studies.

Previous studies have shown that ET in $T$. ramosissima is quite variable across numerous scales and conditions (see Table 1). ET was higher in some previous studies than in this study, ranging from 0 during the winter (Devitt et al., 1998) or for severely stressed T. ramosissima (Devitt et al., 1997a) to over $20 \mathrm{~mm}^{-1 a{ }^{-1}}$ during the late summer (Sala et al., 1996; Table 1). While few in number, studies performed over an entire growing season best illustrated the variability in ET as well as the consumptive water loss of which $T$. ramosissima is capable, and the published ET data from growing season studies was most easily compared to ET estimates in other studies (Table 2). Mean annual ET values tended to be lower in the full year study, averaging not only across the growing season but including the periods before and following plant water consumption (see Hansen \& Gorbach (1997) in Table 1).

The seasonal coefficient of variation at the Sevilleta NWR unflooded site was 38\% (Fig. 2). This level of variability, as well as the mean value, was medial to that in previous long-term studies (Table 1). Of the studies reported in Table 1 that were implemented over an entire season or longer (see Table 2), two reported a range in ET greater than in Figure 2 (Devitt et al., 1997a; Devitt et al., 1998) while the variability in the other two was considerably lower (Hansen \& Gorbach, 1997; Xu et al., 1998). Such 
large ranges in ET variability occur because ET in $T$. ramosissima is responsive to ambient environmental conditions (Fig. 3), and the very high ET values reported from the hot and dry Mojave Desert reflect a regional scale relationship between RH and ET in the southwestern U.S.

The spatial variability in $T$. ramosissima ET from the unflooded to the flooded site was 39\% along the Middle Rio Grande, very close to the 37 and $38 \%$ seasonal coefficients of variation. Flooding at Bosque del Apache NWR supports greater leaf area (Dahm et al., In press), allowing greater water loss to the atmosphere than at the unflooded Sevilleta NWR site (Fig. 5). Flooding typically influences the physiology of a stand of vegetation directly by regulating water relations of riparian plants (Smith et al., 1991). Indirect influences of flooding on ET occur by the control of plant establishment (Van Auken \& Bush, 1988; Molles et al., 1998) and stand age structure (Scott et al., 1997), dictating the type and amount of vegetation in the riparian corridor as well as nutrient availability through decomposition and related nutrient cycling (Molles et al., 1995). While these mechanisms have been used to explain the decline of less stress-tolerant cottonwoods (Populus spp.) in the southwestern U.S. (Busch \& Smith, 1995), T. ramosissima stands are also more active under flooded conditions. Therefore, $T$. ramosissima is best described as a facultative stress tolerant species (DiTomaso, 1998), able to dominate under both dry and wet conditions.

Eddy covariance direct measurements of stand-level $T$. ramosissima ET are underrepresented in Table 1, especially in the four studies that reported ET over a full growing season (Table 2). The difficulties of upscaling physiological parameters, as with scaling up from lysimeters (Xu et al., 1998), have been well discussed by Jarvis \& McNaughton (1986). The primary difficulty in scaling from the leaf to the canopy level is the development of thicker boundary layers and consequentially larger boundary layer resistance at the larger scale. This difficulty is expressed when ET scaled up in Table 1 that were determined as a summation of the number of canopies at a site is compared to measurements made at the stand level. The other three full growing season studies in Tables 1 \& 2 (Devitt et al., 1997a; Hansen \& Gorbach, 1997; Devitt et al., 1998) were performed at the stand-level.

Semi-empirical ET models (modified Blaney-Criddle and Penman-Monteith) produce ET approximations that perform well under very specific conditions. Blaney-Criddle and Penman-Monteith work best for crops which have non-limiting water and nutrient resources and a uniform canopy, requiring near steady-state conditions in the one-dimensional vertical energy balance (Saugier \& Katerji, 1991; Stannard, 1993; Steduto \& Hsiao, 1998). Such is also the case using Bowen Ratio Energy Balance systems, in which departure from steady state conditions or the influence of advective energy flux can strongly inhibit the validity of LE and $\mathrm{H}$ measurements because their ratio is unbounded when the eddy transfer coefficients for momentum and energy deviate from equality (Verma et al., 1978; Motha et al., 1979; Lang et al., 1983). The most extreme cases occur when the solution of the Bowen Ratio indicates that $L E>R_{n}$ 
(Devitt et al., 1998), clearly unlikely if $R_{n}$ is the measure of total energy input to the ecosystem.

Eddy covariance, on the other hand, directly measures all four of the vertical energy flux terms without assuming they balance. In fact, the vertical energy fluxes do not balance during the monsoon season (Fig. 4) and in hot, dry aridlands. Monsoon events are associated with extreme turbulence and spectacular electrical activity. Such events increase the effects of advection, already strong along aridland rivers, by increasing convection across the landscape. Among eddy covariance systems, the 3-dimensional sonic anemometer is currently favored because of its ability to rotate measurement axes (for flux deviations from vertical; Wesely, 1970), its long-term field deployability (relative to one-dimensional sonic or hot wire systems, which can only be used for short periods), and its ability to measure fluxes nearer the top of the canopy (relative to the great height required for propeller systems to overcome their rotational inertia).

It is encouraging that rates of ET in $T$. ramosissima stands are correlated between sites (Fig. 5). An understanding of the physical environment that regulates stand level ET provides a mechanism for comparing ET variability across studies. In this case, temperature of the $T$. ramosissima stand did not relate statistically to ET (Fig. 3B). However, temperature in combination with humidity was strongly $(K=0.02)$ related to ET following the average 25-day movements of large frontal systems that humidified the atmosphere and decreased the driving force for ET (Fig. 3A). Cross site comparisons are possible when climate and meteorology are clearly described. However, riparian ecosystems in arid and semiarid regions experience greater environmental variability, with associated variability in ET, than many other ecosystems, confounding direct comparisons to other ecosystem types.

In tallgrass prairie, for example, the seasonal pattern of ET was more responsive to local precipitation events and can be easily divided into characteristic phenological periods - early growth, peak growth, early senescence, and senescence (Kim \& Verma, 1990). As with the tallgrass prairie, the onset and cessation times of ET from $T$. ramosissima along the Middle Rio Grande coincides well with leaf production and senescence, respectively (Fig. 2). However, the rest of $T$. ramosissima's growing season does not form the characteristic growth peak that the tallgrass prairie does, fluctuating instead in a close relationship with the drying or wetting of the canopy (Fig. 3). This response of ET to canopy RH can be explained in two ways: as a result of atmospheric transport or as a result of the physiology of the plants. The relative importance of physiology and atmosphere is influenced by both spatial scale and vegetation type (Jarvis \& McNaughton, 1986).

Seasonal patterns of ET are of considerable importance when determining water budgets for large river systems. For example, a water budget recently has been compiled for the Middle Rio Grande (Fig. 6) and has become an important science-based tool in the Middle Rio Grande basin during recent La Niña-related drought. Equitable water resource allocation depends upon better knowledge of water supplies and depletions. Because water rights are an issue at the interface of science, 
politics and society (Jackson et al., 2001), much of the information available relating to the water cycle along the Middle Rio Grande has not been published in a peer reviewed forum.

A study by Burkholder (1928) addressed evaporation rates in the Middle Rio Grande. Evaporation data were reported on a monthly basis, facilitating the use of these data in further describing water cycle dynamics throughout the year. The coefficient of variation between monthly evaporation rates was 62.8\% in 1900 and 56.6\% in 1903 (Burkholder, 1928). The coefficient of variation between 1900 and 1903 (Burkholder, 1928), 17.7\% \pm 4.4, is smaller than monthly variation, but it is nonetheless meaningful in its effect on estimating an annual water budget, especially from the surface of Elephant Butte Reservoir (Fig. 6). The magnitude of evaporation (1.2 mm day-1 in December to 10.7 $\mathrm{mm} \mathrm{day}^{-1}$ in June) is not different from $T$. ramosissima ET (Table 1), so the largest difference between ET and E is probably related to land-surface area of sunlit open water versus riparian vegetation.

Estimates of annual ET in the Middle Rio Grande water budget are poorly parameterized. Above San Acacia (see Fig. 1), riparian ET is estimated to average 167 $\times 10^{6} \mathrm{~m}^{3} \mathrm{yr}^{-1}$ (19\% of the total Middle Rio Grande Depletions), ranging from 93 to $241 \times$ $10^{6} \mathrm{~m}^{3} \mathrm{yr}^{-1}$ over a 26-year record (Fig. 6). Below San Acacia, however, further uncertainty is built into the water budget by combining riparian $\mathrm{ET}$, irrigated agriculture and open water evaporation into a single term, estimated at $123 \times 10^{6} \mathrm{~m}^{3} \mathrm{yr}^{-1}(14 \%$ of depletions) and ranging from 99 to $222 \times 10^{6} \mathrm{~m}^{3} \mathrm{yr}^{-1}$. These numbers were generated by solving Blaney-Criddle equation estimates of ET for each vegetation and crop type (Hansen \& Gorbach, 1997) and multiplying that quantity by the 1989 estimate of areal coverage for each vegetation type (Crawford et al., 1993).

This application of a Blaney-Criddle equation using a crop coefficient for $T$. ramosissima developed at Bosque del Apache overestimates ET in areas like the unflooded site in this study because application of a single empirically-based equation does not account for spatial variability in ET along the Middle Rio Grande (Fig. 5). While recent budgets of water resources in central New Mexico are beginning to consider this type of variability, uncertainty is generally given as a single term that is not explicitly defined. Three types of variability and error can be illustrated from this study: spatial, seasonal, and annual. Recognizing mechanistic ways in which these uncertainties relate to physical and biological phenomena will contribute substantially to a better accounting of water depletions from ET in the Middle Rio Grande.

ET varies spatially along the riparian corridor due to both intraspecific (Fig. 5) and interspecific variability. Intraspecific variability occurs both within a reach, from the river's edge to the desert's edge (Devitt et al., 1997a), or between reaches that have different ecosystem structure (Fig. 5). This intraspecific variability is very important in determining a water budget because the structure of the riparian forest changes with age (Schaeffer et al., 2000). It is unknown how the Middle Rio Grande water budget accounts for these phenological differences on the 26-year average ET estimate. 
Another major complication lies in long-term changes in the community composition of a riparian forest. Obtaining accurate species composition information along an entire river is expensive and laborious. The community classifications along the Middle Rio Grande used by the Biological Management Plan for the Middle Rio Grande (Crawford et al., 1993) were obtained from the National Wetlands Inventory (1989) from two survey dates: 1935 and 1989. Over that time, there have been drastic changes from $P$. deltoides-dominated forests to $T$. ramosissima- and $E$. angustifolia-dominated forests. Similar transformations have occurred throughout the western U.S. For example, Rood et al. (1995) reported in Montana a 68\% decline in $P$. deltoides abundance along lower St. Mary River and a 52\% increase in $P$. deltoides abundance along the lower Belly River. Other reaches and rivers in Montana were reported to change in $P$. deltoides density intermediate to these values (Rood et al., 1995). Snyder \& Miller (1992) reported a $17.5 \%$ decline in cottonwood abundance along the upper Colorado River and a 9.3\% increase in cottonwood abundance along the upper Rio Grande over the same 37-year interval. The current water budget accounts for interspecific differences in ET, as well as the areal coverage of each species, but both those parameters are held static. While a new classification is under way using remote sensing, annual variability in community composition remains unknown.

Applying these 3-D eddy covariance ET estimates to canopy characteristics and remote sensing techniques is the next step toward upscaling ET estimates along the entire Middle Rio Grande. Methods of upscaling will require a better understanding of thickness and dynamics of the boundary layer over different vegetation types (Cooper et al., 2000), extent of the footprint under various atmospheric conditions, and the role of advected energy exchange with neighboring ecosystem types. LAI, as well, provides an easily calibrated and simple method to predict ET rates away from towered sites. This study, as the first study to compare full growing season ET estimates at multiple sites along the same river, illustrates the necessity of multiple ground truth points for the application of multispectral information to estimate ET. Further ground truth points in other forest types, along with watershed-wide precipitation and stream discharge characteristics, will considerably improve estimates of ET in the Middle Rio Grande water budget. Such modeling efforts are beginning along the Rio Grande, and the preliminary results promise to improve estimates of consumptive water loss along a riparian corridor.

\section{Summary}

Rates of ET from $T$. ramosissima stands vary in complex patterns through various spatial and temporal scales. Such temporal variability in plant function makes full season estimates of ET crucial for characterizing actual consumptive water loss under natural conditions. Combined with the necessity of collecting full growing season data, three-dimensional eddy covariance demonstrated its efficacy for long-term ET determination as well as closure of the energy balance, both of which greatly limits both Bowen Ratio and semi-empirical model estimates (e.g., Penman-Monteith approximations and modified Blaney-Criddle). Spatial variability in flooding regime, 
consumptive water loss, and vegetation density render simultaneous seasonal measurements of ET necessary for applying these data in regional water budgets. Parameterizing the riparian terms in the water budget with data from one site (e.g., 122 $\mathrm{cm} \mathrm{yr}^{-1}$ at Bosque del Apache NWR) can provide a very different estimate of water loss than using data from another individual site (e.g., $74 \mathrm{~cm} \mathrm{yr}^{-1}$ at Sevilleta NWR). Incorporated into spatial ET variability for $T$. ramosissima is spatial variability in other riparian species (e.g., $P$. deltoides) along the Middle Rio Grande. 3-D eddy covariance data from $T$. ramosissima and $P$. deltoides communities, measured across a full growing season at multiple sites, will greatly assist in the success or failure of planning regional water resources, characterizing and explaining plant invasions, and restoring riparian gallery forests.

\section{Acknowledgments}

We would like to thank Steve Hansen, Salim Bawazir, Padinare Unnikrishna, Manuel Molles, Cliff Crawford, Greg Shore, Laurence Hipps, John Prueger, and Maceo Martinet for their conceptual and methodological assistance. We would like to further thank the Sevilleta National Wildlife Refuge (NWR), and specifically Ron Cornwell, for their assistance with construction of the $10 \mathrm{~m}$ tower near San Acacia, and we wish to thank the Bureau of Reclamation and New Mexico State University for their gracious contribution of space on the $15 \mathrm{~m}$ tower at the Bosque del Apache. For site access, we gratefully acknowledge the Bosque del Apache NWR, the Middle Rio Grande Conservancy District, and the Sevilleta NWR. Further thanks for their ongoing interest are offered to the Hydrogeoecology and the Sevilleta Long Term Ecological Research groups at the University of New Mexico, the New Mexico interagency ET workgroup, and the Bosque Hydrology Group. This research was funded by NASA award NAG5-6999 and the NASA PURSUE program. We would like to finally thank three anonymous reviewers for improving this manuscript.

\section{References}

Anderson, B. (1998). The debate over Tamarisk. Restoration and Management Notes, 16: 129-139.

Anderson, J.E. (1982). Factors controlling transpiration and photosynthesis in Tamarix chinensis Lour. Ecology, 63: 48-56.

Auble, G.T., Friedman, J.M. \& Scott, M.L. (1994). Relating riparian vegetation to present and future streamflows. Ecological Applications, 4: 544-554.

Bayley, P.B. (1995). Understanding large river-floodplain ecosystems. Bioscience, 45: 153-158. 
Brock, J.H. (1994). Tamarix (salt cedar), an invasive exotic woody plant in arid and semi-arid riparian habitats of western USA. In de Waal, L.C., Child, L.E., Wade, P.M. \& Brock, J.H. (Eds). Ecology and Management of Invasive Riverside Plants, pp. 27-44. New York: Wiley \& Sons, Ltd. $232 \mathrm{pp}$.

Burkholder, J.L. (1928). Report of the Chief Engineer: submitting a plan for flood control, drainage and irrigation of the Middle Rio Grande Conservancy Project. Volume 1. Middle Rio Grande Conservancy District, State of New Mexico.

Busch, D.E. \& Smith, S.D. (1995). Mechanisms associated with decline of woody species in riparian ecosystems of the southwestern U.S. Ecological Monographs, 65: 347-370.

Christensen, E.M. (1962). The rate of naturalization of Tamarix in Utah. American Midland Naturalist, 68: 51-57.

Cleverly, J.R., Smith, S.D., Sala, A. \& Devitt, D.A. (1997). Invasive capacity of Tamarix ramosissima in a Mojave Desert floodplain: the role of drought. Oecologia, 111: 12-18.

Cooper, D.I., Eichinger, W.E., Kao, J., Hipps, L., Reisner, J., Smith, S., Schaeffer, S.M. \& Williams, D.G. (2000). Spatial and temporal properties of water vapor and latent energy flux over a riparian canopy. Agricultural and Forest Meteorology, 105: 161-183.

Crawford, C.S., Culley, A.C., Leutheuser, R., Sifuentes, M.S., White, L.H. \& Wilber, J.P. (1993). Middle Rio Grande ecosystem: Bosque biological management plan. U.S. Fish and Wildlife Service, District 2, Albuquerque, New Mexico, 291 pp.

Culler, R.C., Hanson, R.L. \& Jones, J.E. (1976). Relation of the consumptive use coefficient to the description of vegetation. Water Resources Research, 12: 40-46.

Dahm, C.N., Cleverly, J.R., Allred Coonrod, J.E., Thibault, J.R., McDonnell, D.E. \& (In press). Evapotranspiration at the land/water interface in a semi-arid drainage basin. Freshwater Biology, special issue on "Riverine Landscapes".

Davenport, D.C., Martin, P.E. \& Hagan, R.M. (1982). Evapotranspiration from riparian vegetation: water relations and irrecoverable losses for saltcedar. Journal of Soil and Water Conservation, 37: 233-236.

Devitt, D.A., Piorkowski, J.M., Smith, S.D., Cleverly, J.R. \& Sala, A. (1997a). Plant water relations of Tamarix ramosissima in response to the imposition and alleviation of soil moisture stress. Journal of Arid Environments, 36: 527-540.

Devitt, D.A., Sala, A., Mace, K.A. \& Smith, S.D. (1997b). The effect of applied water on the water use of saltcedar in a desert riparian environment. Journal of Hydrology, 192: 233-246.

Devitt, D.A., Sala, A., Smith, S.D., Cleverly, J., Shaulis, L.K. \& Hammett, R. (1998). Bowen ratio estimates of evapotranspiration for Tamarix ramosissima stands on the Virgin River in southern Nevada. Water Resources Research, 34: 2407-2414.

DiTomaso, J.M. (1998). Impact, biology, and ecology of saltcedar (Tamarix spp.) in the southwestern United States. Weed Technology, 12: 326-336. 
Gay, L.W. \& Fritschen, L.J. (1979). An energy budget analysis of water use by saltcedar. Water Resources Research, 15: 1589-1592.

Glenn, E., Tanner, R., Mendez, S., Kehret, T., Moore, D., Garcia, J. \& Valdes, C. (1998). Growth rates, salt tolerance and water use characteristics of native and invasive riparian plants from the delta of the Colorado River, Mexico. Journal of Arid Environments, 40: 281-294.

Hansen, S. \& Gorbach, C. (1997). Middle Rio Grande Water Assessment: Final Report. U.S. Bureau of Reclamation, Albuquerque Area Office. 151 pp.

Jackson, R.B., Carpenter, S.R., Dahm, C.N., McKnight, D.M., Naiman, R.J, Postel, S.L. \& Running, S.W. (2001). Water in a changing world. Ecological Applications, 11: 1027-1045.

Jarvis, P.G. \& McNaughton, K.G. (1986). Stomatal control of transpiration: scaling up from leaf to region. Advances in Ecological Research, 15: 1-49.

Jensen, M.E., Burman, R.D. \& Allen, R.G. (Eds.) (1990). Evapotranspiration and irrigation water requirements. ASCE Manuals and Reports on Engineering Practice, No. 70, ASCE, New York. $332 \mathrm{pp}$.

Kim, J. \& Verma, S.B. (1990). Components of surface energy balance in a temperate grassland ecosystem. Boundary-Layer Meteorology, 51: 401-417.

Kustas, W.P., Prueger, J.H., Hipps, L.E., Hatfield, J.L. \& Meek, D. (1998). Inconsistencies in net radiation estimates from use of several models of instruments in a desert environment. Agricultural and Forest Meteorology, 90: 257-263.

Lang, A.R.G., McNaughton, K.G., Fazu, C., Bradley, E.F. \& Ohtaki, E. (1983). Inequality of eddy transfer coefficients for vertical transport of sensible and latent heats during advective inversions. Boundary-Layer Meteorology, 25: 25-41.

Molles, M.C. \& Dahm, C.N. (1990). A perspective on El-Niño and La-Niña: global implications for stream ecology. Journal of the North American Benthological Society, 9: 68-76.

Molles, M.C., Jr., Crawford, C.S. \& Ellis, L.M. (1995). Effects of an experimental flood on litter dynamics in the Middle Rio Grande ecosystem. Regulated Rivers: Research \& Management, 11: 257-281.

Molles, M.C., Jr., Crawford, C.S., Ellis, L.M., Valett, H.M. \& Dahm, C.N. (1998). Managed flooding for riparian ecosystem restoration. Bioscience, 48: 749-756.

Motha, R.P., Verma, S.B. \& Rosenberg, N.J. (1979). Exchange coefficients under sensible heat advection determined by eddy correlation. Agricultural Meteorology, 20: 273-280.

Prueger, J.H., Hipps, L.E. \& Cooper, D.I. (1996). Evaporation and the development of the local boundary layer over an irrigated surface in an arid region. Agricultural and Forest Meteorology, 78: 223-237.

Robinson, T.W. (1965). Introduction, spread and areal extent of saltcedar (Tamarix) in the Western States. U.S. Geological Survey professional paper 491-A, Washington. 12 pp. 
Rood, S.B., Mahoney, J.M., Reid, D.E. \& Zilm, L. (1995). Instream flows and the decline of riparian cottonwoods along the St. Mary River, Alberta. Canadian Journal of Botany, 73: 1250-1260.

Sala, A., Smith, S.D. \& Devitt, D.A. (1996). Water use by Tamarix ramosissima and associated phreatophytes in a Mojave Desert floodplain. Ecological Applications, 6: 888-898.

Saugier, B. \& Katerji, N. (1991). Some plant factors controlling evapotranspiration. Agricultural and Forest Meteorology, 54: 263-277.

Schaeffer, S.M., Williams, D.G. \& Goodrich, D.C. (2000). Transpiration of cottonwood/willow forest estimated from sap flux. Agricultural and Forest Meteorology, 105: 257-270.

Scott, M.L., Auble, G.T. \& Friedman, J.M. (1997). Flood dependency of cottonwood establishment along the Missouri River, Montana, USA. Ecological Applications, 7: 677-690.

Slack, J.R., Lamb, A.M. \& Landwehr, J.M. (1993). HCDN: Hydro-Climatic Data Network Streamflow Data Set, 1874-1988. U.S. Geological Survey, Water Resources Investigations Report 93-4076.

Smith, S.D., Wellington, A.B., Nachlinger, J.L. \& Fox, C.A. (1991). Functional responses of riparian vegetation to streamflow diversion in the eastern Sierra Nevada. Ecological Applications, 1: 89-97.

Snyder, W.D. \& Miller, G.C. (1992). Changes in riparian vegetation along the Colorado River and Rio Grande, Colorado. Great Basin Naturalist, 52: 357-363.

Stannard, D.I. (1993). Comparison of Penman-Monteith, Shuttleworth-Wallace, and modified Priestley-Taylor evapotranspiration models for wildland vegetation in semiarid rangeland. Water Resources Research, 29: 1379-1392.

Steduto, P. \& Hsiao, T.C. (1998). Maize canopies under two soil water regimes: III. Variation in coupling with the atmosphere and the role of leaf area index. Agricultural and Forest Meteorology, 89: 201-213.

Twine, T.E., Kustas, W.P., Norman, J.M., Cook, D.R., Houser, P.R., Meyers, T.P., Prueger, J.H., Starks, P.J., Wesely, M.L. (2000). Correcting eddy-covariance flux underestimates over a grassland. Agricultural and Forest Meteorology, 103: 279-300.

Van Auken, O.W. \& Bush, J.K. (1988). Dynamics of establishment, growth, and development of black willow and cottonwood in the San Antonio river forest. The Texas Journal of Science, 40: 269-277.

Verma, S.B., Rosenberg, N.J. \& Blad, B.L. (1978). Turbulent exchange coefficients for sensible heat and water vapor under advective conditions. Journal of Applied Meteorology, 17: 330-338.

Wesely, M.L. (1970). Eddy correlation measurements in the atmospheric surface layer over agricultural crops. Ph.D. Thesis, University of Wisconsin, Madison. 80 pp. 
Xu, X., Zhang, R., Xue, X. \& Zhao, M. (1998). Determination of evapotranspiration in the desert area using lysimeters. Communications in Soil Science and Plant Analysis, 29: 1-13. 
Table 1. Published data sources, measurement method, spatial scale, and ET measure for Tamarix ramosissima. Leaf-level data were collected using a leaf chamber on intact plants in the field (in situ).

\begin{tabular}{|c|c|c|}
\hline Study & Method & ET range \\
\hline & & Leaf-level: \\
\hline Anderson, 1982 & in situ & $2.2-2.5 \quad \mathrm{mmol} \mathrm{m}^{-2} \mathrm{~s}^{-1}$ \\
\hline $\begin{array}{l}\text { Busch \& Smith, } \\
1995\end{array}$ & in situ & $3-8 \quad \mathrm{mmol} \mathrm{m}^{-2} \mathrm{~s}^{-1}$ \\
\hline & & Canopy-level: \\
\hline $\begin{array}{l}\text { Gay \& Fritschen, } \\
1979\end{array}$ & Lysimeter & $6.2-9.4 \quad m m$ day $^{-1}$ \\
\hline Sala et al., 1996 & Sap flux & $0.3-0.6 \quad \mathrm{~kg}\left(\mathrm{~m}^{2} \text { leaf area }\right)^{-1} \mathrm{hr}^{-1}$ \\
\hline Cleverly et al., 1997 & Sap flux & $600-1000 \mathrm{~kg}\left(\mathrm{~m}^{2} \text { sapwood area }\right)^{-1} \mathrm{hr}^{-1}$ \\
\hline Devitt et al., 1997a & Sap flux & $0-2.1 \quad \mathrm{~kg}\left(\mathrm{~m}^{2} \text { leaf area }\right)^{-1} \mathrm{hr}^{-1}$ \\
\hline Devitt et al., 1997a & Sap flux & $0-21 \quad \mathrm{~kg}\left(\mathrm{~m}^{2} \text { leaf area }\right)^{-1}$ day $^{-1}$ \\
\hline Devitt et al., 1997b & Sap flux & $200-\quad \mathrm{kg}\left(\mathrm{m}^{2} \text { sapwood area }\right)^{-1} \mathrm{hr}^{-1}$ \\
\hline Glenn et al., 1998 & Lysimeter & $12.9 \pm 0.67 \mathrm{~g}$ (g fresh weight) ${ }^{-1}$ day $^{-1}$ \\
\hline Xu et al., 1998 & Lysimeter & $3.1-3.8 \quad \mathrm{~mm} \mathrm{day}^{-1}$ \\
\hline & & Stand-level: \\
\hline Culler et al., 1976 & Near-IR & $1.3-3.1 \quad \mathrm{~mm} \mathrm{day}^{-1}$ \\
\hline $\begin{array}{l}\text { Gay \& Fritschen, } \\
1979\end{array}$ & Bowen Ratio & $7.2-9.5 \quad m m$ day $^{-1}$ \\
\hline $\begin{array}{l}\text { Davenport et } \\
\text { al., } 1982\end{array}$ & Lysimeter $^{*}$ & $2.2-15.8 \mathrm{~mm}$ day $^{-1}$ \\
\hline Sala et al., 1996 & Sap flux $x^{*}$ & $5.4-20.2 \mathrm{~mm} \mathrm{day}^{-1}$ \\
\hline Sala et al., 1996 & Penman-Monteith & $3.1-8.2 \quad m m$ day $^{-1}$ \\
\hline Devitt et al., 1997a & Penman-Monteith & $\mathrm{mm}$ day $^{-1}$ \\
\hline $\begin{array}{l}\text { Hansen \& Gorbach, } \\
1997\end{array}$ & Blaney-Criddle & $\mathrm{mm}$ day $^{-1}$ \\
\hline Devitt et al., 1998 & Bowen Ratio & $\mathrm{mm}$ day $^{-1}$ \\
\hline
\end{tabular}

\section{* Scaled up from the canopy level}


Table 2. Measurement periods of ET estimates for T. ramosissima in Table 1. The original units are also shown illustrating where the measurement period affected scaling ET to $\mathrm{mm}_{\text {day }}{ }^{-1}$.

\begin{tabular}{|c|c|c|}
\hline Study & Period & units \\
\hline Culler et al., 1976 & point estimates & $\mathrm{ft} \mathrm{mo}-1$ \\
\hline Gay \& Fritschen, 1979 & 14 June - 18 June & $m m$ day $^{-1}$ \\
\hline Anderson, 1982 & $\begin{array}{l}\text { point estimates during } \\
\text { June }\end{array}$ & $\mathrm{g} \mathrm{dm}^{-2} \mathrm{hr}^{-1}$ \\
\hline Davenport et al., 1982 & June, July, August & $\mathrm{mm}$ day $^{-1}$ \\
\hline Busch \& Smith, 1995 & $\begin{array}{l}\text { monthly point } \\
\text { estimates }\end{array}$ & $\mathrm{mmol} \mathrm{m} \mathrm{m}^{-2} \mathrm{~s}^{-1}$ \\
\hline Sala et al., 1996 & 7 July - 18 Oct & $\mathrm{mm}$ day $^{-1}$ \\
\hline Cleverly et al., 1997 & 9 June \& 23 Aug & $\mathrm{kg}\left(\mathrm{m}^{2} \text { sapwood area }\right)^{-1} \mathrm{hr}^{-1}$ \\
\hline Devitt et al., 1997a & full season & $\mathrm{mm}$ day $^{-1}$ \\
\hline Devitt et al., 1997b & 24 Jun \& 5 Aug & $\mathrm{kg}\left(\mathrm{m}^{2} \text { sapwood area }\right)^{-1} \mathrm{hr}^{-1}$ \\
\hline $\begin{array}{l}\text { Hansen \& Gorbach, } \\
1997\end{array}$ & full year & in $\mathrm{yr}^{-1}$ \\
\hline Devitt et al., 1998 & full season & $\mathrm{mm}$ day $^{-1}$ \\
\hline Glenn et al., 1998 & 31 days & $g$ (g shoot fresh weight) $)^{-1}$ day $^{-1}$ \\
\hline Xu et al., 1998 & full season (183 days) & $\mathrm{mm} \mathrm{yr}^{-1}$ \\
\hline
\end{tabular}


Figure 1. Locations of 3-D eddy covariance towers along the Rio Grande, New Mexico. (A) The Rio Grande in New Mexico, USA, and the limits of the Middle Rio Grande watershed. The northern boundary of the Middle Rio Grande is located at Otowi Bridge, north of Cochiti Reservoir. The southern boundary is Elephant Butte Reservoir. (B) Tower locations along the Middle Rio Grande. The two Tamarix ramosissima-dominated sites are at the Sevilleta NWR and the Bosque del Apache NWR.

Figure 2. Daily ET at a Tamarix ramosissima dominated unflooded site. Filled bars represent measured ET values. Striped bars represent estimated ET using a general linear regression between $R_{n}$ and LE, and missing bars represent days when ET could not be estimated. Approximate phenological events, based upon weekly or semiweekly observations, are indicated by the arrows, at which $A=$ greening starts, $B=$ canopy $50 \%$ greening, $C=$ canopy fully green, $D=$ senescence beginning, $E=50 \%$ senescent, and $F$ $=100 \%$ senescent.

Figure 3. Daily maximal temperature $\left(T_{\text {max }} ; A\right.$; solid line), minimal temperature $\left(T_{\text {min }}\right.$; $\mathrm{A}$; dashed line), evapotranspiration (ET; $\mathrm{B}$; solid line), and average relative humidity $(\mathrm{RH}$; $\mathrm{B}$; dashed line) at the Tamarix ramosissima unflooded site. Temperature and $\mathrm{RH}$ were measured at the top of the canopy. Minimum and maximum temperatures were determined daily, as was total ET. Average $\mathrm{RH}$ was calculated from the daytime (i.e., $R_{n}>0$ ) values only. In both $A$ and $B$, the values shown are 5-day running means.

Figure 4. Daily mean daytime $\left(\mathrm{R}_{\mathrm{n}}>0\right)$ energy balance at the $T$. ramosissima unflooded site. Net radiation $\left(R_{n}\right.$; short dashed-dotted line), ground heat flux ( $G$; long dashed-dotted line), sensible heat flux $(\mathrm{H}$; dashed line) and latent heat flux (LE; dotted line) were measured with the 3-d eddy covariance system. Closure (solid line) was computed as $R_{n}-(G+H+L E)$.

Figure 5. Relationship between daily ET measured at Tamarix ramosissima dominated flooded and unflooded sites. Line is least squares regression $(p<0.0001)$.

Figure 6. A partial water budget for the Middle Rio Grande. The budget presented here was modified from a budget prepared by the Action Committee of the Middle Rio Grande Water Assembly in October 1999. Exchanges with the deep aquifer have been omitted for clarity. All values are in units of $\mathrm{m}^{3} \mathrm{~s}^{-1}$. Values are average (rounded). Natural variability is large for most, but not all variabilities are available. Data was included from 1972 through 1997. 
